\title{
ANALYSIS OF SUSTAINABILITY OF ECONOMIC SECTOR IN PROBOLINGGO DISTRICT EAST JAVA PROVINCE - INDONESIA
}

\author{
Markus Patiung*, Nugrahini Susantinah Wisnujati \\ Magister Agribussines, Agriculture Faculty/ Wijaya Kusuma Surabaya University, Indonesia \\ *corresponding author: markus_uwk@yahoo.co.id
}

\begin{abstract}
Gross Regional Domestic Product (PDRB) is the amount of gross added value arising from all economic sectors in the region. It aims to help formulate regional policies, plan and evaluate development results, and provide information that can describe the regional economic performance. The purpose of this research is to analyse sustainable economic sector in Probolinggo district east Java province - Indonesia. A sustainable sector means a sector that is currently included as a basis and will remain a basis sector in the future even if the growth is slow or fast. The analytical methods used include analysis of Location Quotient (LQ), Dynamic Location Quotient (DLQ), and Klassen Typology. Of the 17 economic sectors that contributed to the PDRB of Probolinggo district, with the results of the LQ analysis, 7 sectors were in basic categories and 10 sectors were in non-basic categories. Results of the comparative analysis of LQ and DLQ indicates that there are 5 leading sectors, 2 prospective sectors, 6 mainstay sectors, and 4 lagging sectors. The results of the classification typology analysis consisted of 3 fastgrowing and fast-growing sectors, 7 sectors is growing fast, 4 advanced and slow-growing sectors, and 3 relatively lagging sectors. From the three analysis results, it can be seen that the sustainable sectors are agriculture, forestry, and fisheries (second rank ); electricity and gas procurement sector (first rank); water supply, waste management, waste and recycling sectors (third rank); health service sector and social activities (fourth rank); other service sectors (rank fifth); processing industry sector; construction sector; transportation and warehousing sector; the accommodation and food and drink provision sector; information and communication sector; and the education services sector.
\end{abstract}

Keywords: Sector, Development, Sustainability, Gross Regional Domestic Product.

http://dx.doi.org/10.21776/ub.agrise.2020.020.4.2

Received 25 August 2020

Accepted 21 October 2020

Available online 30 October 2020

\section{INTRODUCTION}

Background, economic growth is one of the benchmarks that can be used to increase the development of a region from various economic sectors indirectly to describe the rate of economic change (Twuska 2018). China has succeeded in achieving high levels of economic growth for almost 40 years. It is said that the size of the GDP of a country has no relationship with the quality of life of people, what matters is how the benefits of economic growth are distributed among the people (source) Therefore, the economic performance of a nation must be assessed, no less important development. In Iran analysis of environmental sustainability, with Pareto programming optimizing cost minimization, minimizing carbondioxide emissions, and maximizing job opportunities were created (Atabaki and Aryanpur 2018) Economic growth and its processes are the main requirements for sustainable regional economic development. Because sustainable population growth means that economic needs also increase so that additional income is needed every year (Amalia 2019). To optimize local economic development in an autonomous era which refers to Law no. 32 of 2004 concerning Local Government, automatically requires local governments to be globally oriented. This causes competition between countries to get higher and will have an impact on the Indonesian economy, especially 
in the regions. Therefore, the government's challenge is no longer autonomy or decentralization, but each region is required to improve its competitiveness (Tampilang, Koleangandan, and Wauran 2012). It should be realized that the selection of leading sectors is not only adjusted to regional characteristics but the strategy for accelerating regional development itself in the form of comparative and competitive advantages (Ziyadaturrofiqoh, Zulfanetti, and Safari 2018); (Safri and Hidayat 2018). One important indicator to determine economic conditions in a region at a certain period is through Gross Regional Domestic Product (GRDP) data, both at current prices and constant prices. GRDP is the amount of added value generated by all business units in a particular country or is the total value of final goods and services produced by all economic units (BPS Probolinggo, 2020) The success of economic development is seen through economic growth, where economic growth can be measured one of which uses the Gross Regional Domestic Product (GRDP).

The problem is, of the 17 economic sectors that contribute to GRDP, it is not yet known which sectors can be sustainable. Because it could be that the current sector is said to be a basis but with changes in the local economy it can turn into a non-basic sector in the future, or vice versa, a sector that is now non-basis but can become a basis sector in the future. Hence, the purpose of this research is to analyse sustainable economic sector in Probolinggo district east Java province Indonesia.

\section{RESEARCH METHODS}

This research was conducted in Probolinggo Regency in 2020, using secondary data, the data used were the PDRB data of Probolinggo Regency and the PDRB data of East Java Province. The analytical methods used are Location Quotient (LQ), Dynamic Location Quotient (DLQ), and Klassen Typology. The Location Quotient (LQ) method is used to determine which sectors are classified as basis and sectors that are classified as nonbasis. Meanwhile, the Dynamic Location Quotient (DLQ) method is used to determine which sectors in the regions are growing faster or slower than those of the same sector in the national scope. The comparison of LQ and DLQ results can determine whether the sector is included in the leading, prospective, reliable, or underdeveloped sectors. Klassen typology method is used to determine fast-growing and fast-growing sectors, fast-growing sectors, advanced and slowgrowing sectors, and / or relatively underdeveloped sectors. The LQ formula is: Where:
However, the calculation formula used in this study is (Budiharsono 2001):

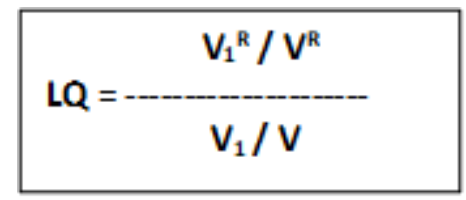

Where:

$\mathrm{V}_{1}{ }^{\mathrm{R}}$ : The value of GRDP of a district level sector Probolinggo

$\mathrm{V}^{\mathrm{R}}$ : The value of GRDP of all district level sectors Probolinggo

V1: The value of GRDP of a sector at the provincial level in East Java

$\mathrm{V}$ : The value of GRDP of all sectors at the provincial level in East Java

Based on the location quotient (LQ) analysis, if the value of LQ> 1 then the sector becomes the basis or potential, the resulting product can not only meet the needs in the region but can also be exported outside the region. The higher the LQ value than one, the higher the comparative advantage (Cahyono, S Andy and Wijaya 2014);(R. Jumiyanti 2018);(Hartarto 2016);(Sapriadi and Hasbiullah 2015). Conversely, if the value of LQ $<1$, then the sector is classified as non-basis, has no advantage / non-potential, the production of that sector in a region cannot fulfill its own needs so it needs supplies or imports from outside. If the value of $\mathrm{LQ}=$ 1 , the sector is classified as non-basis, has no advantages, the production of that sector is only able to meet the needs of the region itself and cannot be exported.

Changes in the local economy over a certain period of time can be tested through Dynamic Location Quotient (DLQ) so that sectoral changes can be identified. DLQ is a modified form of SLQ by accommodating the amount of GRDP from a sector or sub-secto's production value. The rise and fall of LQ can be seen for certain sectors at different time dimensions with the following formulations (Nazipati 2007)

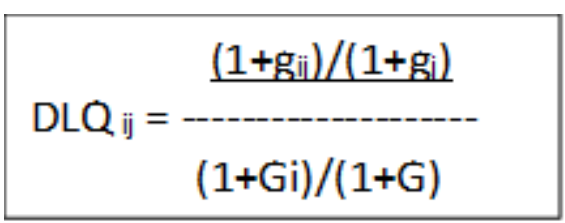

DLQij: Sector potential i index at the district level;

$\mathrm{g}_{i j} \quad$ : The rate of added value growth in sector $\mathrm{i}$ at the district level;

$\mathrm{g}_{j} \quad$ : The average GNP growth rate at 
district level;

$\mathrm{Gi}$ : The rate of added value growth in sector $\mathrm{i}$

at the provincial level;

G : Average GNP growth at the level

Province.

The DLQ value is more than 1 , then the potential development of sector $i$ in a region is faster than that of the same sector in the national scope. Conversely, if the DLQ $<1$, then the potential for sector $i$ development in the region is lower than the national as a whole.

The comparison between SLQ / LQ and DLQ values can be used as a criterion in determining whether an economic sector is classified as superior, prospective, reliable, and underdeveloped. The criteria are as follows (Dewi and Yasa 2018);(Suyatno 2007):

a.If the value of LQ and DLQ> 1, the leading sector means that the sector will remain the basis for both now and in the future.

b. If the value of LQ> 1 and DLQ $<1$, the sector is prospective, it means that the sector will shift from a base sector to a non-basis in the future.

c. If the value of LQ $<1$ and DLQ $>1$ is a mainstay sector, it means that the sector will shift from a non-base sector to a basic sector in the future.

d. If the value of LQ and DLQ $<1$, the sector is lagging, meaning that the sector will continue to be non-basis both now and in the future.

Formula: Klassen Typology

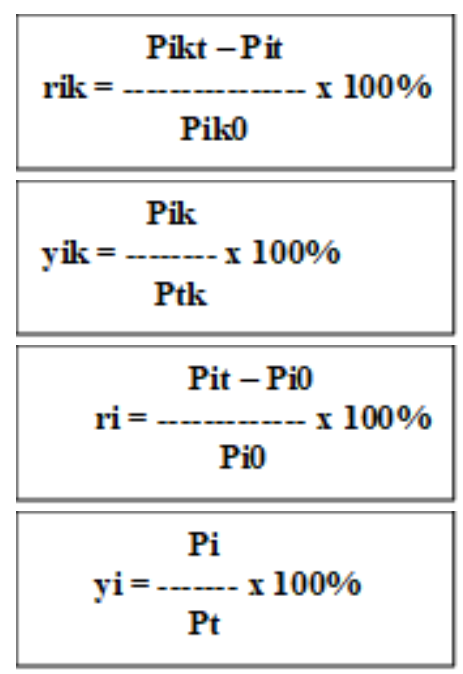

Information:

rik $=$ The rate of growth in the value of production at level Probolinggo district

ri $=$ The rate of growth in the value of production $i$ at level East Java Province

yik $=$ Contribution $\mathrm{i}$ to the total value of production

level Probolinggo district $\mathrm{yi}=$ Contribution $\mathrm{i}$ to the total value of production level East Java Province

Where :

Pikt $=$ District level production value of sector $\mathrm{i}$

Probolinggo in year $\mathrm{t}$

Piko $=$ District level production value of sector $\mathrm{i}$

Probolinggo at the beginning of the year

Pit $=$ Production value of sector $i$ at the provincial level in Java East in year $\mathrm{t}$

Pio $=$ Production value of sector $i$ at the provincial level in Java East at the start of the year

Pik = Production value of sector $i$ at district level

Probolinggo

Ptk = total district level production value

Probolinggo

$\mathrm{Pi}=$ Production value of sector $\mathrm{i}$ at the provincial level in Java East

$\mathrm{Pt}=$ total production value at the provincial level of East Java

Table 1. Klaseen Typology of Sector Growth

\begin{tabular}{|c|l|c|}
\hline $\begin{array}{l}\text { Laju } \\
\text { pertumbuhan }\end{array}$ & yik>yi & yik<yi \\
\hline rik>ri & $\begin{array}{l}\text { Sektor } \\
\text { maju dan } \\
\text { tumbuh } \\
\text { cepat }\end{array}$ & $\begin{array}{l}\text { Sektor } \\
\text { berkembang } \\
\text { cepat }\end{array}$ \\
\hline rik<ri & $\begin{array}{l}\text { Sektor } \\
\text { maju dan } \\
\text { tumbuh } \\
\text { lambat }\end{array}$ & $\begin{array}{l}\text { Sektor } \\
\text { relatif } \\
\text { tertinggal }\end{array}$ \\
\hline
\end{tabular}

\section{RESULTS AND DISCUSSION}

Based on the results of the Location Quotient analysis of 17 economic sectors on the PDRB data of Probolinggo Regency based on constant prices for 2015-2019, it was found that the base sector on which there were 7 sectors, namely: agriculture, electricity and gas procurement, water supply, waste management, disposal and recycling, the real estate sector, government administration, and compulsory social security, the health services sector and social activities, and other service sectors. Meanwhile, 10 non-basic sectors. The details of the basis and nonbasic sectors are as shown in Table 2 below. 
Table 2. Result of Location Quotient (LQ) Analysis of Economic Sectors Probolinggo Regency East Java Indonesia in 2019

\begin{tabular}{|c|c|c|c|}
\hline No & Bussines Sector & LQ & Criteria \\
\hline 1 & $\begin{array}{l}\text { Agriculture, Forestry and } \\
\text { Fisheries }\end{array}$ & 2,70 & Basic \\
\hline 2 & Mining and excavation & 0,60 & Non Basic \\
\hline \multirow[t]{5}{*}{3} & Processing industry & 0,79 & Non Basic \\
\hline & $\begin{array}{l}\text { Procurement of Electricity } \\
\text { and Gas }\end{array}$ & 3,06 & Basic \\
\hline & $\begin{array}{l}\text { Water Supply, Waste } \\
\text { Management, Waste and } \\
\text { Recycling }\end{array}$ & 1,29 & Basic \\
\hline & Construction & 0,77 & Non Basic \\
\hline & $\begin{array}{l}\text { Wholesale Retail Trade; Car } \\
\text { and Motorcycle Repair }\end{array}$ & 0,71 & Non Basic \\
\hline 8 & $\begin{array}{ll}\text { Transportation } & \text { and } \\
\text { Warehousing } & \\
\end{array}$ & 0,26 & Non Basic \\
\hline 9 & $\begin{array}{l}\text { Provision of } \\
\text { Accommodation and Food } \\
\text { and Drink }\end{array}$ & 0,27 & Non Basic \\
\hline 10 & $\begin{array}{ll}\text { Information } & \text { and } \\
\text { Communication } & \end{array}$ & 0,75 & Non Basic \\
\hline 11 & $\begin{array}{lll}\text { Financial } & \text { Services } & \text { and } \\
\text { Insurance } & & \\
\end{array}$ & 0,69 & Non Basic \\
\hline 12 & Real Estate & 1,50 & Basic \\
\hline 13 & Company Services & 0,40 & Non Basic \\
\hline 14 & $\begin{array}{l}\text { Mandatory Government } \\
\text { Administration, Defense and } \\
\text { Social Security }\end{array}$ & 1,37 & Basic \\
\hline 15 & Education Services & 0,12 & Non Basic \\
\hline 16 & $\begin{array}{l}\text { Health Services and Social } \\
\text { Activities }\end{array}$ & 1,00 & Basic \\
\hline 17 & Other Services & 1,42 & Basic \\
\hline
\end{tabular}

The non-base sector signals to the Probolinggo district government and East Java Province to evaluate policies, programs, and development activities that have been implemented and establish appropriate policies to facilitate this non-basic sector to become a base sector in the future. This can be done through the right acceleration/ acceleration activities and appropriate development budgeting.

Dynamics of Economic Sector Movement in the Last Four Years (2015-2019) in Probolinggo Regency

Table 3. Results of Dynamic Location Quotient (DLQ) Analysis of Economic Sectors Probolinggo Regency in 2019

\begin{tabular}{|l|l|c|l|l|}
\hline No & \multicolumn{1}{|c|}{ Business Sector } & LQ & DLQ & Criteria \\
\hline 1 & $\begin{array}{l}\text { Agriculture, Forestry and } \\
\text { Fisheries }\end{array}$ & 2,70 & 1,21 & Superior \\
\hline 2 & Mining and excavation & 0,60 & 0,24 & Left behind \\
\hline 3 & Processing industry & 0,79 & 1,26 & Mainstay \\
\hline 4 & $\begin{array}{l}\text { Procurement of } \\
\text { Electricity and Gas }\end{array}$ & 3,06 & 5,63 & Superior \\
\hline 5 & $\begin{array}{l}\text { Water Supply, Waste } \\
\text { Management, Waste and } \\
\text { Recycling }\end{array}$ & 1,29 & 1,18 & Superior \\
\hline 6 & Construction & 0,77 & 1,52 & Mainstay \\
\hline
\end{tabular}

\begin{tabular}{|c|l|c|c|l|}
\hline 7 & $\begin{array}{l}\text { Wholesale Retail Trade; } \\
\text { Car and Motorcycle } \\
\text { Repair }\end{array}$ & 0,71 & 0,99 & Left behind \\
\hline 8 & $\begin{array}{l}\text { Transportation and } \\
\text { Warehousing }\end{array}$ & 0,26 & 1,31 & Mainstay \\
\hline 9 & $\begin{array}{l}\text { Provision of } \\
\text { Accommodation and } \\
\text { Food and Drink }\end{array}$ & 0,27 & 1,05 & Mainstay \\
\hline 10 & $\begin{array}{l}\text { Information and } \\
\text { Communication }\end{array}$ & 0,75 & 1,27 & Mainstay \\
\hline 11 & $\begin{array}{l}\text { Financial Services and } \\
\text { Insurance }\end{array}$ & 0,69 & 0,93 & Left behind \\
\hline 12 & Real Estate & 1,50 & 0,84 & Prospective \\
\hline 13 & Company Services & 0,40 & 0,86 & Left behind \\
\hline 14 & $\begin{array}{l}\text { Mandatory Government } \\
\text { Administration, Defense } \\
\text { and Social Security }\end{array}$ & 1,37 & 0,83 & Prospective \\
\hline 15 & Education Services & 0,12 & 1,07 & Mainstay \\
\hline 16 & $\begin{array}{l}\text { Health Services and } \\
\text { Social Activities }\end{array}$ & 1,00 & 1,11 & Superior \\
\hline 17 & Other Services & 1,42 & 1,11 & Superior \\
\hline
\end{tabular}

The results of the analysis of Location Quotient and Dynamic Location Quotient are juxtaposed so that the economic potential of each sector is known. From the results of the analysis in Table 2 . It can be seen that the agricultural, forestry and plantation sectors; electricity and gas procurement sector; water supply, waste management, waste and recycling sectors; health service sector and social activities; and other service sectors will remain as a base sector both now and in the future. Research from (Zamida 2017) shows that the Agriculture sector is the base sector. Meanwhile, the real estate sector; the government administration, land, and social security sectors will shift from a basic to a non-basic sector in the future. Processing industry; construction ; the transportation and trade ; the accommodation and food and beverage supply ; information and communication; and the education service sectors will shift from a non-base sector to a basic sector in the future. Mining and quarrying sector; wholesale and retail trade, car and motorcycle repair; the financial services and insurance sector; the corporate service sector is a sector that will remain a non-base sector both now and in the future.

\section{Structure of Economic Growth Patterns in Probolinggo Regency}

The structure of the economic growth pattern can be determined by using Klassen's typology analysis. In Klassen typology, there are two indicators used, namely: growth rate and contribution of each sector in Probolinggo Regency. By determining economic growth as the vertical axis and the average contribution of each sector as the horizontal axis, then it is divided into four classifications or quadrants, namely advanced and fast-growing sectors; the developed sector grows slowly; fast-growing sector; and a sector that is relatively lagging. 
Table 4. Results of Analysis of the Probolinggo Regency's GRDP Growth Rate in 2019

\begin{tabular}{|c|c|c|c|c|c|}
\hline & Bussines Sector & $\mathbf{y}_{\mathrm{ik}}$ & $\mathbf{y}_{\mathbf{i}}$ & $\mathbf{r}_{\mathrm{ik}}$ & $\mathbf{r}_{\mathbf{i}}$ \\
\hline A & $\begin{array}{l}\text { Agriculture, } \\
\text { Forestry and } \\
\text { Fisheries }\end{array}$ & 34,03 & 12,55 & 0,12 & 2,77 \\
\hline B & $\begin{array}{l}\text { Mining and } \\
\text { excavation }\end{array}$ & 2,41 & 4,02 & 2,14 & 6,74 \\
\hline $\mathrm{C}$ & $\begin{array}{l}\text { Processing } \\
\text { industry }\end{array}$ & 23,41 & 29,5 & 8,57 & 6,73 \\
\hline $\mathrm{D}$ & $\begin{array}{l}\text { Procurement of } \\
\text { Electricity and } \\
\text { Gas }\end{array}$ & 0,99 & 5,46 & 4,96 & 2,70 \\
\hline $\bar{E}$ & $\begin{array}{l}\text { Water Supply, } \\
\text { Waste } \\
\text { Management, } \\
\text { Waste and } \\
\text { Recycling }\end{array}$ & 0,12 & 0,09 & 5,00 & 4,59 \\
\hline $\mathrm{F}$ & Construction & 7,41 & 9,62 & 8,16 & 5,90 \\
\hline G & $\begin{array}{l}\text { Wholesale Retail } \\
\text { Trade; Car and } \\
\text { Motorcycle } \\
\text { Repair } \\
\end{array}$ & 12,82 & 18,05 & 6,91 & 7,06 \\
\hline $\mathrm{H}$ & $\begin{array}{l}\text { Transportation } \\
\text { and Warehousing }\end{array}$ & 0,89 & 3,41 & 8,41 & 6,60 \\
\hline I & $\begin{array}{l}\text { Provision of } \\
\text { Accommodation } \\
\text { and Food and } \\
\text { Drink }\end{array}$ & 1,51 & 5,73 & 8,12 & 7,89 \\
\hline $\mathrm{J}$ & $\begin{array}{l}\text { Information and } \\
\text { Communication }\end{array}$ & 3,38 & 4,58 & 7,73 & 6,23 \\
\hline $\mathrm{K}$ & $\begin{array}{l}\text { Financial Services } \\
\text { and Insurance }\end{array}$ & 1,87 & 2,72 & 5,09 & 5,50 \\
\hline $\mathrm{L}$ & Real Estate & 2,44 & 1,62 & 5,26 & 6,40 \\
\hline & $\begin{array}{l}\text { Company } \\
\text { Services }\end{array}$ & 0,33 & 0,82 & 6,08 & 7,14 \\
\hline $\mathrm{O}$ & $\begin{array}{l}\text { Mandatory } \\
\text { Government } \\
\text { Administration, } \\
\text { Defense and } \\
\text { Social Security }\end{array}$ & 3,18 & 2,32 & 4,27 & 6,69 \\
\hline & $\begin{array}{l}\text { Education } \\
\text { Services }\end{array}$ & 2,62 & 2,65 & 5,90 & 5,56 \\
\hline & $\begin{array}{l}\text { Health Services } \\
\text { and Social } \\
\text { Activities }\end{array}$ & 0,63 & 0,63 & 6,84 & 6,25 \\
\hline $\begin{array}{l}\mathrm{R} \\
\mathrm{S} \\
\mathrm{T} \\
\mathrm{U}\end{array}$ & Other Services & 1,97 & 1,38 & 5,17 & 5,24 \\
\hline
\end{tabular}

Based on the results of the analysis of the growth rate and contribution of the Probolinggo Regency GRDB sector in 2019 in table 4 it can be seen that the manufacturing industry sector; water supply, waste processing, waste and recycling sectors; Real estate sector; the health services sector and social activities are developed and growing fast. Agriculture, forestry, and fisheries sectors; mandatory government administration, defense, and social security sectors; as well as other service sectors are developed and slowgrowing sectors, in Russia effective policies aimed at the sustainable development of the agricultural sector, because it is important to achieve SDGs
Russia's agricultural potential is the most important one that will enable the sustainable development of the agricultural sector, taking into account local, regional and global perspectives (Bogoviz 2019); electricity and gas procurement sector, construction sector; wholesale and retail trade, car and motorcycle repair; the transportation and warehousing sector; the accommodation and food and beverage supply sector; information and communication sector; and the education services sector is a fast-growing sector. While the mining and quarrying sector; the financial services and insurance sector; and the corporate service sector is relatively underdeveloped.

Table 5. Results of the Analysis of the Contribution of the Probolinggo Regency PDRB Sector in 2019

\begin{tabular}{|c|c|c|c|c|}
\hline & $\begin{array}{c}\text { Bussiness } \\
\text { Sector } \\
\end{array}$ & $\begin{array}{l}\text { Growth } \\
\text { Rate } \\
\end{array}$ & $\begin{array}{c}\text { Contrib } \\
\text { ution }\end{array}$ & $\begin{array}{c}\text { Sector } \\
\text { Criteria } \\
\end{array}$ \\
\hline A & $\begin{array}{l}\text { Agriculture, } \\
\text { Forestry and } \\
\text { Fisheries }\end{array}$ & $\mathrm{r}_{\mathrm{ik}}<\mathrm{r}_{\mathrm{i}}$ & $\mathbf{y}_{\mathrm{ik}}>\mathbf{y}_{\mathbf{i}}$ & $\begin{array}{c}\text { Advanced \& } \\
\text { slow growing } \\
\text { sector }\end{array}$ \\
\hline B & $\begin{array}{l}\text { Mining and } \\
\text { excavation }\end{array}$ & $\mathrm{r}_{\mathrm{ik}}<\mathrm{r}_{\mathrm{i}}$ & $\mathbf{y}_{\mathrm{ik}}<\mathbf{y}_{\mathrm{i}}$ & $\begin{array}{l}\text { The sector is } \\
\text { relatively } \\
\text { lagging behind }\end{array}$ \\
\hline $\mathrm{C}$ & $\begin{array}{l}\text { Processing } \\
\text { industry }\end{array}$ & $r_{i k}>r_{i}$ & $\mathbf{y}_{\mathbf{i k}}>\mathbf{y}_{\mathbf{i}}$ & $\begin{array}{c}\text { Advanced \& } \\
\text { fast growing } \\
\text { sector } \\
\end{array}$ \\
\hline D & $\begin{array}{l}\text { Procurement } \\
\text { of Electricity } \\
\text { and Gas }\end{array}$ & $r_{i k}>r_{i}$ & $\mathbf{y}_{\mathrm{ik}}<\mathbf{y}_{\mathbf{i}}$ & $\begin{array}{l}\text { Fast growing } \\
\text { sector }\end{array}$ \\
\hline $\mathrm{E}$ & $\begin{array}{l}\text { Water } \\
\text { Supply, } \\
\text { Waste } \\
\text { Management, } \\
\text { Waste and } \\
\text { Recycling } \\
\end{array}$ & $\mathrm{r}_{\mathrm{ik}}>\mathrm{r}_{\mathrm{i}}$ & $\mathbf{y}_{\mathbf{i k}}>\mathbf{y}_{\mathbf{i}}$ & $\begin{array}{l}\text { Advanced \& } \\
\text { fast growing } \\
\text { sector }\end{array}$ \\
\hline $\mathrm{F}$ & Construction & $\mathrm{r}_{\mathrm{ik}}>\mathrm{r}_{\mathrm{i}}$ & $\mathbf{y}_{\mathrm{ik}}<\mathbf{y}_{\mathbf{i}}$ & $\begin{array}{l}\text { Fast growing } \\
\text { sector }\end{array}$ \\
\hline G & $\begin{array}{l}\text { Wholesale } \\
\text { Retail Trade; } \\
\text { Car and } \\
\text { Motorcycle } \\
\text { Repair }\end{array}$ & $\mathrm{r}_{\mathrm{ik}}>\mathrm{r}_{\mathrm{i}}$ & $\mathbf{y}_{\mathbf{i k}}<\mathbf{y}_{\mathbf{i}}$ & $\begin{array}{l}\text { Fast growing } \\
\text { sector }\end{array}$ \\
\hline $\mathrm{H}$ & $\begin{array}{l}\text { Transportatio } \\
\mathrm{n} \text { and } \\
\text { Warehousing }\end{array}$ & $r_{i k}>r_{i}$ & $\mathbf{y}_{\mathrm{ik}}<\mathbf{y}_{\mathbf{i}}$ & $\begin{array}{l}\text { Fast growing } \\
\text { sector }\end{array}$ \\
\hline I & $\begin{array}{l}\text { Provision of } \\
\text { Accommodati } \\
\text { on and Food } \\
\text { and Drink }\end{array}$ & $r_{i k}>r_{i}$ & $\mathbf{y}_{\mathbf{i k}}<\mathbf{y}_{\mathbf{i}}$ & $\begin{array}{l}\text { Fast growing } \\
\text { sector }\end{array}$ \\
\hline $\mathrm{J}$ & $\begin{array}{l}\text { Information } \\
\text { and } \\
\text { Communicati } \\
\text { on }\end{array}$ & $r_{i k}>r_{i}$ & $\mathbf{y}_{\mathbf{i k}}<\mathbf{y}_{\mathbf{i}}$ & $\begin{array}{l}\text { Fast growing } \\
\text { sector }\end{array}$ \\
\hline $\mathrm{K}$ & $\begin{array}{l}\text { Financial } \\
\text { Services and } \\
\text { Insurance } \\
\end{array}$ & $\mathrm{r}_{\mathrm{ik}}<\mathrm{r}_{\mathrm{i}}$ & $\mathbf{y}_{\mathbf{i k}}<\mathbf{y}_{\mathbf{i}}$ & $\begin{array}{l}\text { The sector is } \\
\text { relatively } \\
\text { lagging behind }\end{array}$ \\
\hline $\mathrm{L}$ & Real Estate & $\mathrm{r}_{\mathrm{ik}}>\mathrm{r}_{\mathrm{i}}$ & $\mathbf{y}_{\mathbf{i k}}>\mathbf{y}_{\mathbf{i}}$ & $\begin{array}{c}\text { Advanced \& } \\
\text { fast growing } \\
\text { sector }\end{array}$ \\
\hline $\begin{array}{l}\mathrm{M} \\
\mathrm{N}\end{array}$ & $\begin{array}{l}\text { Company } \\
\text { Services }\end{array}$ & $\mathrm{r}_{\mathrm{ik}}<\mathrm{r}_{\mathrm{i}}$ & $\mathbf{y}_{\mathrm{ik}}<\mathbf{y}_{\mathbf{i}}$ & $\begin{array}{l}\text { The sector is } \\
\text { relatively } \\
\text { lagging behind }\end{array}$ \\
\hline $\mathrm{O}$ & $\begin{array}{l}\text { Mandatory } \\
\text { Government } \\
\text { Administrati } \\
\text { on, Defense } \\
\text { and Social } \\
\text { Security }\end{array}$ & $\mathrm{r}_{\mathrm{ik}}<\mathrm{r}_{\mathrm{i}}$ & $\mathbf{y}_{\mathbf{i k}}>\mathbf{y}_{\mathbf{i}}$ & $\begin{array}{l}\text { Advanced \& } \\
\text { slow growing } \\
\text { sector }\end{array}$ \\
\hline
\end{tabular}

Volume XX, Number 4 (2020): 277-284 


\begin{tabular}{|c|c|c|c|c|}
\hline $\mathrm{P}$ & $\begin{array}{l}\text { Education } \\
\text { Services }\end{array}$ & $r_{i k}>r_{i}$ & $y_{i k}<y_{i}$ & $\begin{array}{l}\text { Fast growing } \\
\text { sector }\end{array}$ \\
\hline Q & $\begin{array}{l}\text { Health } \\
\text { Services and } \\
\text { Social } \\
\text { Activities }\end{array}$ & $r_{i k}>r_{i}$ & $\mathbf{y}_{\mathrm{ik}}>\mathbf{y}_{\mathbf{i}}$ & $\begin{array}{l}\text { Advanced \& } \\
\text { fast growing } \\
\text { sector }\end{array}$ \\
\hline $\begin{array}{l}\mathrm{R}, \\
\mathrm{S}, \\
\mathrm{T}, \\
\mathrm{U}\end{array}$ & $\begin{array}{l}\text { Other } \\
\text { Services }\end{array}$ & $\mathrm{r}_{\mathrm{ik}}<\mathrm{r}_{\mathrm{i}}$ & $y_{i k}>y_{i}$ & $\begin{array}{l}\text { Advanced \& } \\
\text { slow growing } \\
\text { sector }\end{array}$ \\
\hline
\end{tabular}

Based on the results of the analysis of the growth rate and contribution of the Probolinggo Regency PDRB sector in 2019 in Table 3 it can be seen that the manufacturing industry sector; water supply, waste processing, waste and recycling sectors; real estate sector; the health services sector and social activities are developed and growing fast. Agriculture, forestry, and fisheries sectors; mandatory government administration, defense, and social security sectors; as well as other service sectors are developed and slow-growing sectors. In Russia effective policies aimed at the sustainable development of the agricultural sector, because it is important to achieve SDGs. (Bogoviz, Aleksei 2019)

Russia's agricultural potential is the most important one that will enable the sustainable development of the agricultural sector, taking into account local, regional and global perspectives (Bogoviz 2019); electricity and gas procurement sector, construction sector; wholesale and retail trade, car and motorcycle repair; the transportation and warehousing sector; the accommodation and food and beverage supply sector; information and communication sector; and the education services sector is a fast-growing sector. While the mining and quarrying sector; the financial services and insurance sector; and the corporate service sector is relatively underdeveloped.

Table 6 Result Of LQ,DLQ and Class Typology

\begin{tabular}{|l|l|l|l|l|}
\hline No & $\begin{array}{c}\text { Result LQ } \\
\text { Analysis } \\
\text { LQ } \\
\text { Analysis }\end{array}$ & $\begin{array}{l}\text { Result } \\
\text { Comparati } \\
\text { DL }\end{array}$ & $\begin{array}{c}\text { Klassen } \\
\text { Typology }\end{array}$ \\
\hline 1 & $\begin{array}{l}\text { Agriculture, } \\
\text { Forestry and } \\
\text { Fisheries }\end{array}$ & Basic & Superior & $\begin{array}{l}\text { Advanced } \\
\text { \& slow } \\
\text { growing } \\
\text { sector }\end{array}$ \\
\hline 2 & $\begin{array}{l}\text { Mining and } \\
\text { excavation }\end{array}$ & $\begin{array}{l}\text { Non } \\
\text { Basic }\end{array}$ & Left behind & $\begin{array}{l}\text { The sector } \\
\text { is relatively } \\
\text { lagging } \\
\text { behind }\end{array}$ \\
\hline 3 & $\begin{array}{l}\text { Processing } \\
\text { industry }\end{array}$ & $\begin{array}{l}\text { Non } \\
\text { Basic }\end{array}$ & Mainstay & $\begin{array}{l}\text { Advanced } \\
\text { \& fast } \\
\text { growing } \\
\text { sector }\end{array}$ \\
\hline 4 & $\begin{array}{l}\text { Procurement } \\
\text { of Electricity } \\
\text { and Gas }\end{array}$ & Basic & Superior & $\begin{array}{l}\text { Fast } \\
\text { growing } \\
\text { sector }\end{array}$ \\
\hline
\end{tabular}

Agricultural Socio-Economics Journal

\begin{tabular}{|c|c|c|c|c|}
\hline No & $\begin{array}{c}\text { Result LQ } \\
\text { Analysis }\end{array}$ & $\begin{array}{l}\text { Result } \\
\text { LQ } \\
\text { Analysis }\end{array}$ & $\begin{array}{c}\text { LQ And } \\
\text { DLQ } \\
\text { Comparati } \\
\text { on } \\
\end{array}$ & $\begin{array}{c}\text { Klassen } \\
\text { Typology }\end{array}$ \\
\hline 5 & $\begin{array}{l}\text { Water } \\
\text { Supply, } \\
\text { Waste } \\
\text { Management, } \\
\text { Waste and } \\
\text { Recycling }\end{array}$ & Basic & Superior & $\begin{array}{l}\text { Advanced } \\
\& \text { fast } \\
\text { growing } \\
\text { sector }\end{array}$ \\
\hline 6 & Construction & $\begin{array}{l}\text { Non } \\
\text { Basic }\end{array}$ & Mainstay & $\begin{array}{l}\text { Fast } \\
\text { growing } \\
\text { sector }\end{array}$ \\
\hline 7 & $\begin{array}{c}\text { Wholesale } \\
\text { Retail Trade; } \\
\text { Car and } \\
\text { Motorcycle } \\
\text { Repair }\end{array}$ & $\begin{array}{l}\text { Non } \\
\text { Basic }\end{array}$ & Left behind & $\begin{array}{l}\text { Fast } \\
\text { growing } \\
\text { sector }\end{array}$ \\
\hline 8 & $\begin{array}{c}\text { Transportatio } \\
\mathrm{n} \text { and } \\
\text { Warehousing }\end{array}$ & $\begin{array}{l}\text { Non } \\
\text { Basic }\end{array}$ & Mainstay & $\begin{array}{c}\text { Fast } \\
\text { growing } \\
\text { sector }\end{array}$ \\
\hline 9 & $\begin{array}{l}\text { Provision of } \\
\text { Accommodati } \\
\text { on and Food } \\
\text { and Drink }\end{array}$ & $\begin{array}{l}\text { Non } \\
\text { Basic }\end{array}$ & Mainstay & $\begin{array}{c}\text { Fast } \\
\text { growing } \\
\text { sector }\end{array}$ \\
\hline 10 & $\begin{array}{c}\text { Information } \\
\text { and } \\
\text { Communicati } \\
\text { on }\end{array}$ & $\begin{array}{l}\text { Non } \\
\text { Basic }\end{array}$ & Mainstay & $\begin{array}{c}\text { Fast } \\
\text { growing } \\
\text { sector }\end{array}$ \\
\hline 11 & $\begin{array}{l}\text { Financial } \\
\text { Services and } \\
\text { Insurance }\end{array}$ & $\begin{array}{l}\text { Non } \\
\text { Basic }\end{array}$ & Left behind & $\begin{array}{c}\text { The sector } \\
\text { is relatively } \\
\text { lagging } \\
\text { behind }\end{array}$ \\
\hline 12 & Real Estate & Basic & Prospektif & $\begin{array}{l}\text { Advanced } \\
\& \text { slow } \\
\text { growing } \\
\text { sector }\end{array}$ \\
\hline 13 & $\begin{array}{c}\text { Company } \\
\text { Services }\end{array}$ & $\begin{array}{l}\text { Non } \\
\text { Basic }\end{array}$ & Left behind & $\begin{array}{c}\text { The sector } \\
\text { is relatively } \\
\text { lagging } \\
\text { behind }\end{array}$ \\
\hline 14 & $\begin{array}{c}\text { Mandatory } \\
\text { Government } \\
\text { Administrati } \\
\text { on, Defense } \\
\text { and Social } \\
\text { Security } \\
\end{array}$ & Basic & prospektif & $\begin{array}{l}\text { Advanced } \\
\& \text { slow } \\
\text { growing } \\
\text { sector }\end{array}$ \\
\hline 15 & $\begin{array}{l}\text { Education } \\
\text { Services }\end{array}$ & $\begin{array}{l}\text { Non } \\
\text { Basic }\end{array}$ & Mainstay & $\begin{array}{c}\text { Fast } \\
\text { growing } \\
\text { sector }\end{array}$ \\
\hline 16 & $\begin{array}{c}\text { Health } \\
\text { Services and } \\
\text { Social } \\
\text { Activities } \\
\end{array}$ & Basic & Superior & $\begin{array}{c}\text { Advanced } \\
\& \text { fast } \\
\text { growing } \\
\text { sector }\end{array}$ \\
\hline 17 & $\begin{array}{l}\text { Other } \\
\text { Services }\end{array}$ & Basic & Superior & $\begin{array}{l}\text { Advanced } \\
\& \text { slow } \\
\text { growing } \\
\text { sector }\end{array}$ \\
\hline
\end{tabular}

The agriculture, forestry, and fisheries sectors are currently the basic and leading sectors and will remain the base sectors in the future even though their growth is slow. The mining and quarrying sector is currently classified as a non-basic and underdeveloped sector and will remain a lagging sector in the future. The manufacturing sector is currently a non-base sector, and is a mainstay as well as advanced and fast-growing but will shift to 
a basic sector in the future. The electricity and gas procurement sector is currently included in the basic sector, leading and growing fast and will remain the basis for the future. The water supply, waste management, waste, and recycling sector is currently a basic, leading, advanced, and fastgrowing sector and will remain a base sector for the foreseeable future. The construction sector is currently a basic, leading, advanced, and fastgrowing sector and will continue to be the basis for the future. Wholesale and retail trade sector; car and motorcycle repair is currently a non-basic sector, lagging, and growing rapidly but will remain a non-base sector and lagging in the future. The transportation and warehousing sector is currently a non-basic, mainstay sector, growing rapidly but will shift from a non-base sector to a base in the future. The provision of accommodation and food and drink sector is currently a non-basic, mainstay, and fast-growing sector and will become a center for the future. The information and communication sector is currently included in the non-base sector, is a mainstay, and is developing fast and will shift to a base sector in the future. The financial services and insurance sector is currently a non-basic sector, lagging and will remain a nonbasic sector and lagging in the future. The real estate sector is currently a basic, prospective, advanced, and fast-growing sector but will shift from a stale to a non-basic sector in the future. The corporate service sector is currently a non-base sector, lagging and will remain a non-base sector and lagging in the future. The Government Administration, Defense, and Compulsory Social Security sector is currently a basic, prospective, advanced, and slow-growing sector but will shift from a basic sector to a non-basic sector in the future. The education service sector is currently a non-basic sector, leading and growing rapidly but will shift from a non-base actor to a basic sector in the future. The health service sector and social activities are currently basic, leading advanced and growing fast and will remain a base sector in the future. Other service sectors are currently the basic sector, leading advanced and slow-growing but will remain as a base sector in the future, but no less important is an effective monitoring and estimation system for implementation efficiency because many of the documents do not have a monitoring and estimation system. Effective implementation efficiency is in line with the principles and practical manifestations of the concept of sustainable development at the national level (Kvak, 2017). The LQ and DLQ approach still has the disadvantage of only grouping the GRDP regions and sectors in the company cluster based on their parameter values. There is a new approach that combines Klassen, LQ, and hierarchies agglomerative grouping (HAC) into a new method called multi-view, hierarchical agglomerative grouping (MVHAC) (Munandar et al., 2018), Besides that, the LQ research can also collaborate with the BCG matrix on research on changes in import conditions at the port of Gwang which has decreased coal imports (Mo et al., 2020)

\section{CONCLUSION}

The results of the analysis show that:

1. Sustainable sectors are:

a. Agriculture, forestry and plantation sectors; electricity and gas procurement sector; water supply, waste management, waste and recycling sectors; health service sector and social activities; and other service sectors will remain the base sector both now and in the future.

b. Processing industry sector; construction sector; the transportation and trade sector; the accommodation and food and beverage supply sector; as well as a developed and fast-growing information and communication sector; and the education service sector will shift from a nonbase sector to a basic sector in the future.

2. Unsustainable sectors are:

a.The real estate sector; the government administration, land, and social security sectors will shift from a basic to a non-basic sector in the future.

b.Mining and quarrying sector; wholesale and retail trade, car and motorcycle repair; the financial services and insurance sector; the corporate service sector is a sector that will remain a non-base sector both now and in the future.

\section{REFERENCES}

Amalia, Afifah Fauziah. (2019). Analisis Pengaruh Pendapatan Asli Daerah, Dana Alokasi Umum, Dan Belanja Modal Terhadap Tingkat Kemandirian Keuangan Daerah Pada Pemerintah Daerah Kabupaten/Kota Di Provinsi Jawa Tengah Tahun 2012-2017. Diponegoro Journal of 
Accounting 8(2): 1-13.

Atabaki, Mohammad Saeid, and Vahid Aryanpur. (2018). Multi-Objective Optimization for Sustainable Development of the Power Sector: An Economic, Environmental, and Social Analysis of Iran. Energy 161: 493-507.

Bogoviz, Aleksei. (2019). Transforming the Agricultural Sector for Better Sustainable Development: Perspectives from Russia as a Member State of the Eurasian Economic Union. IOP Conference Series: Earth and Environmental Science 274(1): 0-5.

BPS Probolinggo. (2020). Produk Domestik Regional Bruto Kabupaten Probolinggo Menurut Pengeluaran.

Budiharsono, S. (2001). Teknik Analisis Pembangunan Wilayah Pesisir Dan Lautan. Pradnya Paramita.

Cahyono, S Andy and Wijaya, Wahyu Wisnu. (2014). Pendapatan Antar Kabupaten Di Sub DAS Bengawan Solo Hulu ( Identification of the Leading Economic Sectors and Income Disparity among Regencies in Upper Bengawan Solo Sub Watershed ). Jurnal Penelitian Sosial dan Ekonomi Kehutanan 11(1): 32-43.

Dewi, Ni Made Winda Savitri, and I Nyoman Mahendra Yasa. (2018). Perencanaan Pembangunan Di Kabupaten Karangasem. 7: 152-83.

Hartarto, Romi Bhakti. (2016). Identifikasi Potensi Ekonomi Kecamatan Tanjungsari Kabupaten Gunungkidul Yogyakarta. Jurnal Ekonomi \& Studi Pembangunan 17(1): 16-21.

Kvak, Mariya. (2017). State Targeted Programs As the Basis for Sustainable Development Policy Implementation in Ukraine. Economic Analysis 12(27(1)): 43-48.

Mo, Soo Won, Kwang Bae Lee, Yong Joo Lee, and Hong Gyun Park. (2020). Analysis of Import Changes through Shift-Share, Location Quotient and BCG Techniques: Gwangyang Port in Asia. Asian Journal of Shipping and Logistics 36(3): 145-56.
Munandar, Tb Ai, Azhari, Aina Musdholifah, and Lincolin Arsyad. (2018). Multiview Hierarchical Agglomerative Clustering for Identification of Development Gap and Regional Potential Sector. Journal of Computer Science 14(1): 81-91.

Nazipati. (2007). Aplikasi Model Static dan Dynamic Location Quotients dan Shift-Share dalam Perencanaan Ekonomi Regional (Studi Kasus Kabupaten Ogan Komering Ulu Propinsi Sumatera Selatan). EKO-REGIONAL 2.

R. Jumiyanti, Kalzum. (2018). Analisis Location Quotient Dalam Penentuan Sektor Basis Dan Non Basis Di Kabupaten Gorontalo. Gorontalo Development Review 1(1): 29.

Sapriadi, and Hasbiullah. (2015). Analisis Penentuan Sektor Unggulan Perekonomian Kabupaten Bulukumba. Jurnal Iqtisaduna 1(1): 53-71.

Suyatno, Suyatno. (2007). Analisa Economic Base Terhadap Pertumbuhan Ekonomi Daerah Tingkat II Wonogiri : Menghadapiimplementasi Uu No. 22/1999 Dan Uu No. 5/1999. Jurnal Ekonomi Pembangunan: Kajian Masalah Ekonomi dan Pembangunan 1(2): 144.

Tampilang, Maxthasen, Rosalina Koleangandan, and Patrick Wauran. (2012). Analisis Potensi Perekonomian Daerah Kabupaten Kepulauan Talaud. : 32-46.

Twuska, Faisal. (2018). Analysis Of Economic Potentials Of Lampung Province By Economic Base Model Approach.

Zamida. (2017). ANALISIS SEKTOR BASIS DI KABUPATEN LAMONGAN ( ANALISIS LOCATION QUOTIENT). DEVELOP 1(1).

Ziyadaturrofiqoh, Zulfanetti, and Muhammad Safari. (2018). Pengaruh PDRB, Upah Minimum Provinsi Dan Pengeluaran Pemerintah Terhadap Penyerapan Tenaga Kerja Di Provinsi Jambi. Jurnal Ekonomi Sumberdaya dan Lingkungan 7(1): 2303-1220. 